\title{
ジルコニウムプロポキシドを用いた多孔質ガラスの化学修飾
}

\author{
川村浩敏・樽田誠一・田草川信雄・北島图夫 \\ 信州大学工学部物質工学科, 380 長野市若里 500
}

\section{Chemical Modification of Porous Glass Using Zirconium Propoxide}

\author{
Hirotoshi KAWAMURA, Seiichi TARUTA, Nobuo TAKUSAGAWA and Kunio KITAJIMA \\ Department of Chemistry and Material Engineering, Faculty of Engineering, Shinshu University, 500, Wakasato, Nagano-shi 380
}

\begin{abstract}
A porous glass specimen, having a mean pore diameter of $10 \mathrm{~nm}$, was prepared from fluorine containing sodium borosilicate glass. Two types of specimens (PG-S and PG-B) were impregnated with $\mathrm{Zr}$-propoxide by the sol-gel method. PG-S had larger pores containing less residual silica-gel. PG-B had larger and smaller pores containing less and larger amounts of residual silica-gel, respectively. Zr-propoxide in pores was converted into $\mathrm{Zr}$-oxide by drying at room temperature and heating at $500^{\circ} \mathrm{C}$. These treatments of impregnation and conversion were repeated up to 5 times. $\mathrm{ZrO}_{2}$ was identified as tetragonal zirconia. The amount of anchored $\mathrm{ZrO}_{2}$ in pores increased with increasing number of the treatment. $\mathrm{ZrO}_{2}$ precipitated mainly in the larger pores and these larger pores decreased in pore size. Therefore, the inhomogeneous pore size distribution was adjusted to become homogeneous by the treatment with $\mathrm{Zr}$-propoxide. The alkali resistance of porous glass specimens was improved by this chemical modification to some extent.
\end{abstract}

[Received May 17, 1996; Accepted August 6, 1996]

Key-words : Porous glass, Zirconium propoxide, Silica-gel, Alkali resistance

\section{1. 緒 言}

ソーダホウケイ酸塩系ガラスを熱処理によって, シリカリッ チガラス相とソーダホウ酸塩ガラス相の二相に分相させ, 酸処 理によって後者を溶出させる方法で多孔質ガラスが調製され る $^{1)}$.この多孔質ガラスは, 機能性物質の担体 ${ }^{2) ~ 5), ~ フ ィ ル ~}$ ター6), HPLC 用カラム充填剤7)等の機能をもっている. また, 最近では多孔質ガラスを用いた膜乳化技術が医学分野でも注目 されている8).

しかし，このような材料として多孔質ガラスを利用するため にはまだ課題が残されている. 気体分離膜等に利用する場合, 細孔表面の改質及び細孔径を $\mathrm{nm}$ オーダーで精密に制御するこ とが必要であり, 簡単な細孔制御方法の開発が望まれている. 守屋らは, ゾル-ゲル法を用いた細孔制御法を検討し, その可 能性を示している ${ }^{9)}$. また, 多孔質ガラスは $96 \%$ 以上がシリカ 成分であるが，水溶液に対してわずかに溶解するために，その 利用範囲が制限されている．例えば，バイオリアクターに利用 する場合，処理物質の残骸をアルカリ溶液で洗浄することが必 要であり, 多孔質ガラスのアルカリ耐久性が重要である.

$\mathrm{SiO}_{2}-\mathrm{ZrO}_{2}$ 系多孔質ガラスは, 原料ガラスとして $\mathrm{SiO}_{2}-\mathrm{ZrO}_{2}-$ $\mathrm{Na}_{2} \mathrm{O}-\mathrm{RO}(\mathrm{R}=\mathrm{Zn}, \mathrm{Ca}, \mathrm{Ba})$ 系ガラスを用いる方法で森本 $\left.{ }^{10}\right)$,

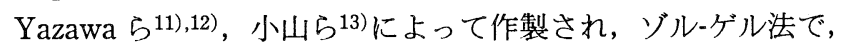
野上 ${ }^{14)}$, Kamiya ら ${ }^{15)}$, 矢沢ら ${ }^{16)}$ ，釣田と和田 ${ }^{17)}$ とって作製 され，その化学的耐久性が研究されている. それらによると， 原料ガラス組成にジルコニアを添加することで, 多孔質ガラス のアルカリ耐久性が著しく向上したと報告されている.

多孔質体への機能性物質の担持方法として, ゾル-ゲル

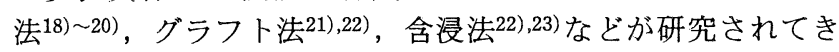
た。 その結果, ゾル-ゲル法及びグラフト法では均一に機能性 物質を担持できるとされている22)。しかし，多孔質体中での 担持成分の分布については詳細な研究は行われていない.

含フッ素ソーダホウケイ酸塩ガラスから調製した多孔質ガラ スはバイコールガラスより大きい細孔をもっているため, ゾル が含浸しやすいうえ，フッ素添加により分相する二相の相互溶 解度が上がり, 細孔中に多量のシリカゲルを残留させることが
できる.したがって, 試験片表面付近と中心部の細孔径の差を より顕著に制御することができる特徵を有している，本研究で は, 含フッ素ソーダホウケイ酸塩ガラスから細孔中の残留シリ カゲル量が異なる二種類の多孔質ガラス試験片を調製し，それ らにジルコニウムアルコキシド溶液を充填し，ゲル化させ，焼 成する処理を繰り返して細孔表面にジルコニア相を生成させ た。 そして，それらの試験片についてジルコニアの分布状態, 細孔径分布及び化学的耐久性を検討した.

\section{2. 実験方法 \\ 2.1 多孔質ガラス試験片の作製}

\section{1 .1 原料ガラスの調製}

特級試薬の, フッ化ナトリウム, 炭酸ナトリウム, 無水ホウ 酸, 無水ケイ酸を $\mathrm{NaF} 4.77, \mathrm{Na}_{2} \mathrm{O} 3.84, \mathrm{~B}_{2} \mathrm{O}_{3} 24.8, \mathrm{SiO}_{2} 66.59$ (mass\%) 組成に相当する割合に混合した。この混合物を $900^{\circ} \mathrm{C}$ で $45 \mathrm{~min}$ 仮焼し, $500 \mu \mathrm{m}$ 以下に粉砕し, $1450^{\circ} \mathrm{C}$ で $4 \mathrm{~h}$ 白 金容器 ( $850 \mathrm{~mm}$, 高さ70 mm) 中で溶融し, 白金容器中で炉 外放冷して原料ガラスとした．なお，原料ガラス中のフッ素含 有量はフッ素イオン電極法で測定した。この方法で, フッ素含 有量が $1.5 \pm 0.05$ mass \%の原料ガラス（直径 $50 \mathrm{~mm}$, 高さ 40 $\mathrm{mm}$ ）を調製した.

\subsection{2 相分離処理及び酸処理}

原料ガラスを $500^{\circ} \mathrm{C} て ゙ 100 \mathrm{~h}$ 加熱して相分離させた．この相 分離処理ガラスを厚さ $1.0 \mathrm{~mm}$ で $15 \times 15 \mathrm{~mm}$ の板状に切断し， それらの表面を\#3000微粒研磨剂で研磨して試験片とした。 この試験片に 2 種類の異なる条件の酸処理 $\mathrm{A}$ 又は $\mathrm{B}$ を行っ た. 酸処理 $\mathrm{A}$ では, 試験片 $1 \mathrm{~g}$ 当たり $200 \mathrm{ml}$ の $0.5 \mathrm{~mol} / 1$ 硫酸 (以下ではこの硫酸量を $\mathrm{ml} / \mathrm{g}$ で表示する) 中につるし, $92^{\circ} \mathrm{C}$ で50h 保持した. 酸処理 B では, $1000 \mathrm{ml} / \mathrm{g}$ の硫酸中に $96 \mathrm{~h}$ 保 持した. 酸処理後の試験片を蒸留水で洗浄し, $60^{\circ} \mathrm{C} て ゙ 24 \mathrm{~h}$ 乾燥 した. 既に報告したように ${ }^{24)}$, 酸処理 $\mathrm{A}$ のような少量の硫酸 を用い短時間の処理で調製した多孔質ガラスには, 試験片の中 心部に比較的多量のシリカゲルが残留し, 細孔径分布曲線は 2 本のピークをもつ (bimodal) ので, 以下ではこの多孔質ガ 
ラスを $\mathrm{PG}-\mathrm{B}$ の記号で表す。また，酸処理 B のような多量の 硫酸で長時間処理して調製した多孔質ガラスには残留シリカゲ ルが少なく，細孔径分布曲線は 1 本のピークを持つ（single modal）ので，以下ではこの多孔質ガラスを PG-S の記号で表 す.

\section{2 ジルコニウムプロポキシド溶液の調製及び充填}

n-プロパノールにアセチルアセトン, アンモニア水, 蒸留水 を加えて室内䨌囲気で $2 \min$ かはんした。そこに，ジルコ ニウム $n$-プロポキシドを加え, 室温, 密封下で $1 \mathrm{~h}$ かくはん してゾルとした。各成分の混合比は， $\mathrm{Zr}\left[\mathrm{O}-\mathrm{n}-\mathrm{C}_{3} \mathrm{H}_{7}\right]_{4}$ : $n-\mathrm{C}_{3} \mathrm{H}_{7} \mathrm{OH}: \mathrm{CH}_{3} \mathrm{COCH}_{2} \mathrm{COCH}_{3}: \mathrm{NH}_{4} \mathrm{OH}: \mathrm{H}_{2} \mathrm{O}=1: 2: 0.18$ : $2.0 \times 10^{-3}: 1.6 \times 10^{-3}$ （モル比）とした．このゾルに多孔質ガ ラス試験片 PG-B 及び PG-S を浸し，毛細管現象を利用して 充填後, 更に $70 \mathrm{cmHg}$ で30 min 減圧してゾルを充填した。こ れを, 室温大気中で $3 \mathrm{~d}$ 放置してゲル化させた後, $500^{\circ} \mathrm{Cで}$ $2 \mathrm{~h}$ 焼成した．以後この処理をジルコニア処理と呼ぶ.このジ ルコニア処理を 1〜5 回繰り返してジルコニア担持多孔質ガラ スとした

\section{3 測定及び観察}

ジルコニア担持多孔質ガラスについて, 試験片の重量増加の 測定, $\mathrm{X}$ 線回折 (XRD)（理学電機製；RAD-1）による結晶相 の同定, X 線マイクロアナライザー（島津製作所製 ; EPMAC1, MODEL40）による試験片中のジルコニウムの分布測定, 電界放射型走査型電子顕微鏡（日立製作所製； FE-SEM, S4100）による微構造観察, 窒素吸着法（Micromeritics 社製; ASAP2000）による細孔径分布，比表面積，細孔容積の測定 を行った．また，試験片のアルカリ耐久性を比較するために， $40^{\circ} \mathrm{C}$ の $1 \mathrm{~mol} / 1$ の水酸化ナトリウム水溶液中に $4 \mathrm{~h}$ 浸積し, 重 量減少率及び目視観察を行った。

\section{3. 実験結果}

\section{1 試験片の重量増加}

多孔質ガラス PG-B と PG-S にジルコニア処理を 1〜 5 回 行った試料の重量変化を図 1 に示した. 処理回数が増加すると 試験片の重量は増加した。 ただし, 多量のシリカゲルが残留し ている PG-B では, 3 回以上の処理による重量増加率は小さく なり, ジルコニアの充填が進行していないことを示している. ジルコニア処理に使用したゾルからバルクゲルを調製した。そ れを $500^{\circ} \mathrm{C} て ゙ ~ 2 \mathrm{~h}$ 焼成して得た試料の真密度（ピクノメーター

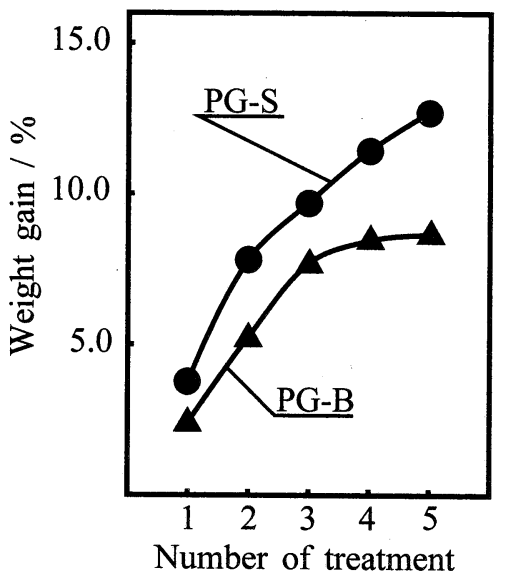

Fig. 1. Weight gain of the porous glass specimens after being treated with the sol and calcined at $500^{\circ} \mathrm{C}$ for $2 \mathrm{~h}$.
法）は， $4.900 \mathrm{~g} / \mathrm{cm}^{3}$ であった．この真密度と試験片の重量増 加からジルコニアの充填量を見積もると，1〜5回をでの処理 で試験片 $1 \mathrm{~g}$ 当たり PG-B では $0.178 \times 10^{-3} \sim 0.816 \times 10^{-3}$ $\mathrm{mol}, \mathrm{PG}-\mathrm{S}$ では $0.314 \times 10^{-3} \sim 1.18 \times 10^{-3} \mathrm{~mol}$ のジルコニアが 担持されたことになる。

\section{$3.2 \times$ 線回折}

ジルコニア処理した多孔質ガラス試験片 PG-S 及び比較物 質としてゾルを室温大気中で 2 か月間放置し， $500^{\circ} \mathrm{C}$ で $2 \mathrm{~h}$ 焼 成した試料の XRD 測定を行った。その結果を図 2 に示した。 ジルコニア処理した PG-S の回折線には，ゲルの熱処理物と 同様に，正方晶ジルコニアのピークが観察された。

\section{3 ジルコニウムの濃度分布}

ジルコニア処理した試験片の破断面について，EPMA を用 いた線分析法でジルコニウムの濃度分布を調べた。その結果を 図 3 に示した. (a) は PG-Bのシルコニア処理試料，(b)は PG-S のジルコニア処理試料中のジルコニウムの分布を示して いる. いずれの試験片でも処理回数の増加に伴い, 試験片の表 面付近のジルコニウム濃度は中心部より大きくなった．また， 多量のシリカゲルが残留する PG-B では, 試験片の中心部の ジルコニウム濃度は極めて小さいことが分かる。

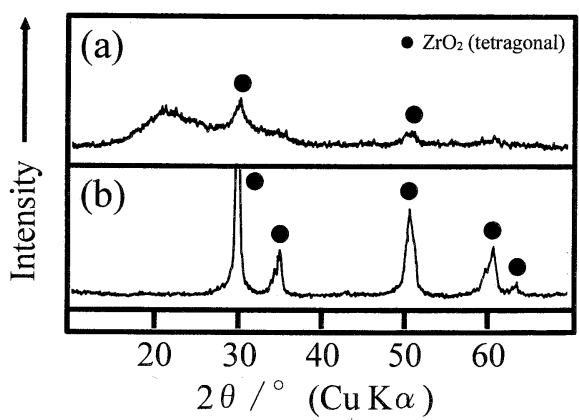

Fig. 2. X-ray diffraction patterns of (a) the $\mathrm{ZrO}_{2}$ anchored porous glass (PG-S) (treatment : 5 times) and (b) dry gel (calcined: $500^{\circ} \mathrm{C}, 2 \mathrm{~h}$ ).

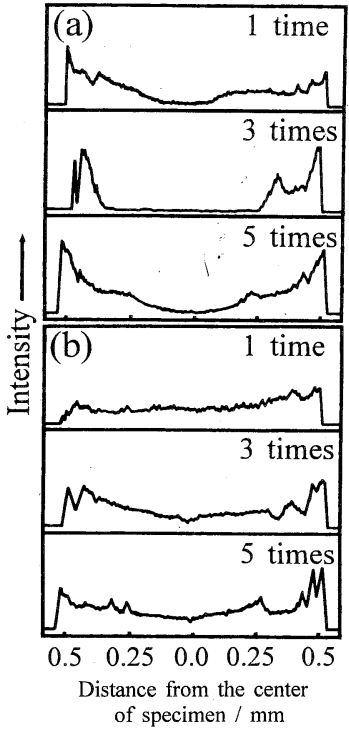

Fig. 3. EPMA line profiles of zirconium for fracture surface of the $\mathrm{ZrO}_{2}$ anchored porous glasses (a) PG-B and (b) PG-S. The repeating times for the $\mathrm{ZrO}_{2}$-treatment are shown in figure. 


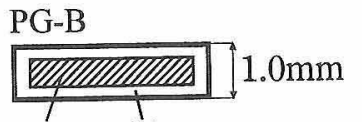

(a) (b)
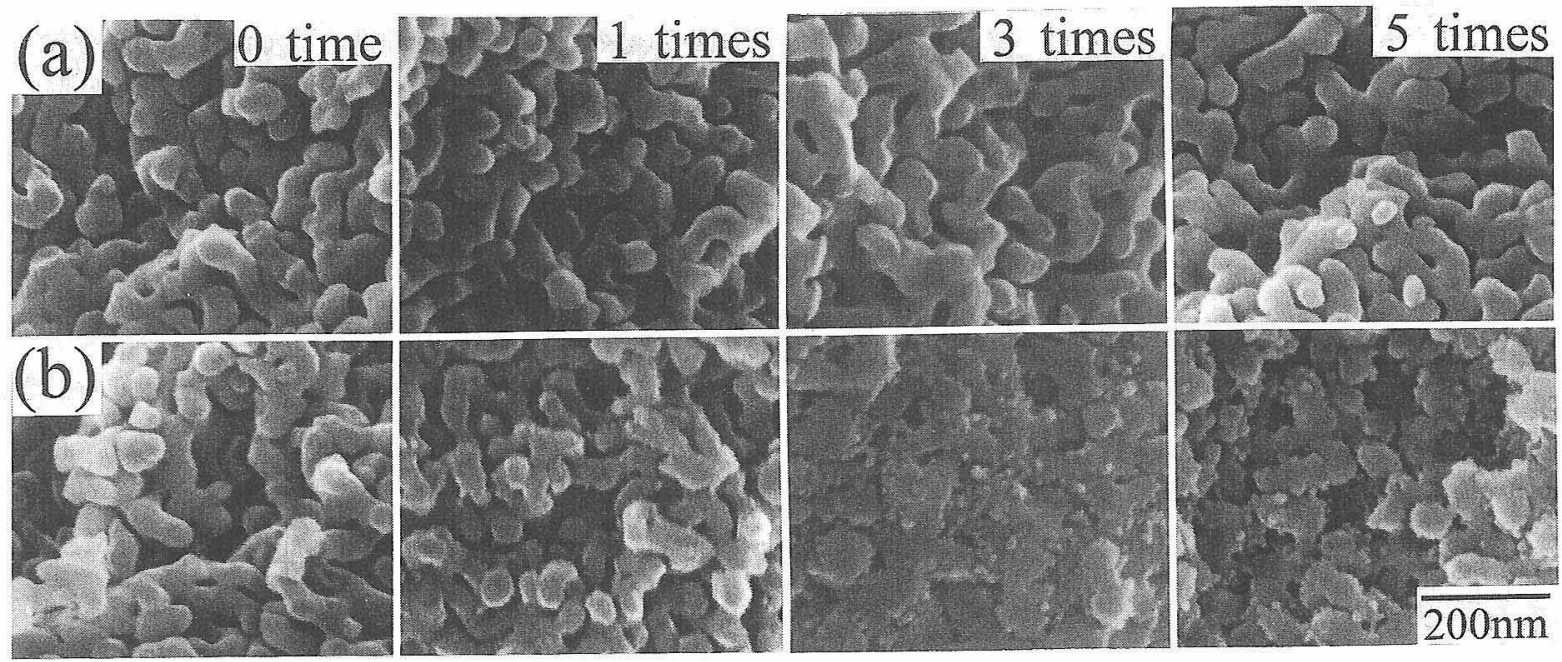

Fig. 4. SEM photographs of the $\mathrm{ZrO}_{2}$ anchored porous glass (PG-B) calcined at $500^{\circ} \mathrm{C}$ for $2 \mathrm{~h}$.

(a) The fracture surface of the inner part of specimen containing a larger amount of residual silica-gel.

(b) The fracture surface near the surface of specimen containing a smaller amount of residual silica-gel.

\section{4 微構造の観察}

ジルコニア处理を行った PG-B の破断面について, 試験片 の表面に近い部分（表面層）上内部（中心層）のSEM 観察を 行った。主な写真を図 4 に示した。いずれの写真にも直径的 $20 \mathrm{~nm}$ 以下の細孔が観察された。この大きさは細孔径分布測 定結果とほほ一一致した，処理回数の増加に伴い表面層には，約 $10 \mathrm{~nm}$ 以下の粓径の多数の微粒子状析出物が観察された。し かし，この析出物は処理回数を增しても中心層には観察されな かった。これらの微粒子は，XRD 及びEPMAの結果から， 不均一に分布したジルコニア微粒子であると判定される。

\section{5 細孔径分布・比表面皘及び細孔容皘の測定}

多孔質ガラス $\mathrm{PG}-\mathrm{B}, \mathrm{PG}-\mathrm{S}$ 及びそれらにジルコニア処理を $1 \sim 5$ 回行った試料の細孔径分布曲線を図 5 に示した. PG-B の細孔径分布曲線には二本のピークが生じた。一方，PG-S の 細孔径分布曲線には一本のピークが生じた。前述のように， PG-Bでは，酸処理液が少なく処理時間が短いために，試験片 の表面層はシリカゲルが除去されて細孔径が大きいが, 試験片 内部の細孔にはシリカゲルが残留し細孔径が小さくなった。こ れに対してPG-Sでは, 酸処理液が多く処理時間も長いため に，試験片内部の細孔からもシリカゲルが除去されている. PG-B の細孔径分布曲線では，ジルコニア処理回数の増加に伴 い2 本のピーク中, 大きい細孔径側のピークが小さくなり， ブロードな 1 本のピークに変化した。 したがって, 試験片表 面層の比較的大きな細孔にジルコニアが担持したと推察された. PG-S の細孔径分布曲線の1本のピークは, ジルコニア処理回 数が増加すると，小さい細孔径側にシフトしてブロードとなり， PG-B と同樣の結果となった.

図 5 と同じジルコニア処理物の, 比表面積及び細孔容積を 図 6 に示した. 処理回数の増加に伴い，比表面積は增加したが 4 又は 5 回以上の処理では減少した。 たた，細孔容積は単調に 減少した.

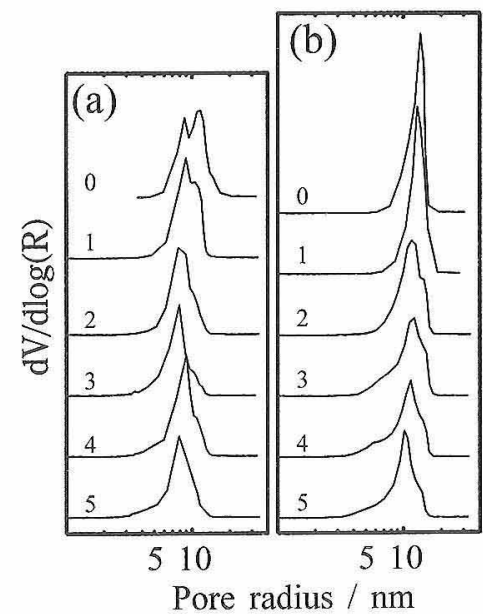

Fig. 5. Pore size distribution curves of the $\mathrm{ZrO}_{2}$ anchored porous glass specimens, (a) PG-B and (b) PG-S, calcined at $500^{\circ} \mathrm{C}$ for $2 \mathrm{~h}$. Numbers in the figure show the repeating times for the $\mathrm{ZrO}_{2}$-treatment.

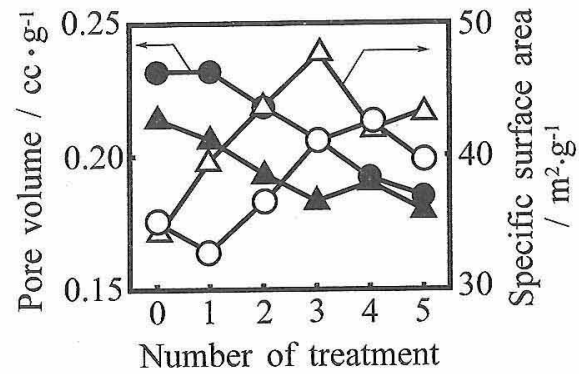

Fig. 6. Specific surface area and pore volume of the $\mathrm{ZrO}_{2}$ anchored porous glasses. Specimen : $\triangle \triangle \mathrm{PG}-\mathrm{B}, \bigcirc \mathrm{PG}-\mathrm{S}$ 


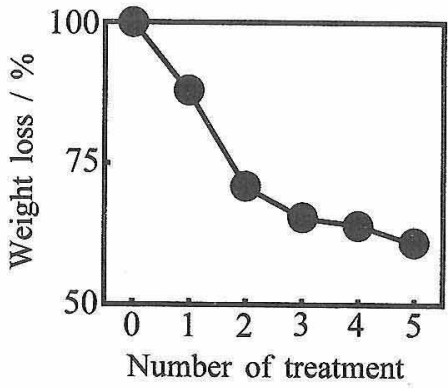

Fig. 7. Relationship between the number of treatment and weight loss of the $\mathrm{ZrO}_{2}$ anchored porous glass (PG-S) immersed in $1.0 \mathrm{~mol} / 1 \mathrm{NaOH}$ solution at $40^{\circ} \mathrm{C}$ for $4 \mathrm{~h}$.

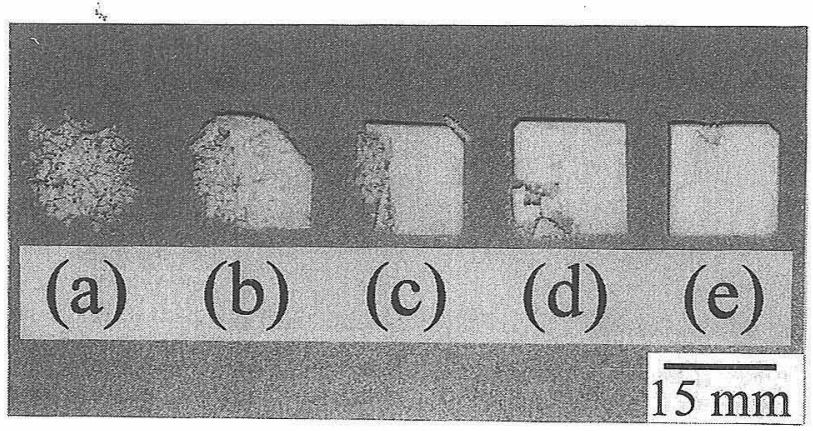

Fig. 8. Pictures of the $\mathrm{ZrO}_{2}$ anchored porous glass samples (PGS) treated with $1.0 \mathrm{~mol} / 1 \mathrm{NaOH}$ solution at $40^{\circ} \mathrm{C}$ for $4 \mathrm{~h}$. The number of the $\mathrm{ZrO}_{2}$-treatment : (a) 1 time, (b) 2 times, (c) 3 times, (d) 4 times and (e) 5 times.

\section{6 アルカリ耐久性試験}

多孔質ガラス $\mathrm{PG}-\mathrm{S}$ に 1 5 回のジルコニア処理を行った試 験片を, $40^{\circ} \mathrm{C} の 1.0 \mathrm{~mol} / 1 \mathrm{NaOH}$ 溶液に $4 \mathrm{~h}$ 浸し, その重量变 化を測定し，試験片の外観を比較した。 その結果をそれぞれ 図 7 放び図 8 に示した. なお，PG-S は残留シリカゲルが少な くジルコニアが比較的均一に充填された試験片である。ジコ ニア処理をしない試験片は $4 \mathrm{~h}$ の処理で完全に溶解し，1回の 処理物む粒状に崩壊したが，更に処理回数が増加すると重量減 少が小さくなり，3〜5 回の処理では重量減少は未処理物のそ れの約 $60 \%$ まで小さくなり，原形が保たれるようになった。 このことは，ジルコニア妈理で多孔質ガラスのアルカリ耐久性 が向上する可能性を示している.

\section{4. 考察}

ジルコニア処理で試験片内に担持されたジルコニアは，1回 の処理で試験片 $1 \mathrm{~g}$ 当たり約 $0.035 \mathrm{~g}$ に相当し, 処理回数とと

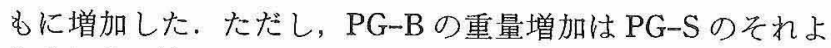
り少なく, 特に, 4 回以上の処理では担持量の増加は少ない。 これは，PG-Bの中心部に多量のシリカゲルが残留し，細孔径 が PG-Sより約30\%小さく，細孔容積も小さいため，ゾルが 試験片内部京で侵入しなかったと考えられる，なお，担持され たジルコニアはXRD 図から正方晶であると判定された。

多孔質ガラス細孔内のジルコニウムの濃度分布は，図 3 の EPMA 測定結果で示したように, PG-B では表面層の濃度が 大きく不均一であったが，PG-S では均一な分布状態であり， このことはジルコニア処理回数が増加しても同様であった．既 報で示したように ${ }^{24)}, \mathrm{PG}-\mathrm{B}$ の試験片の中心部にはシリカゲル が多量に残留しその部分の細孔容積が比較的小さいので，試験
片の中心部に含浸されるゾルが少なくなりジルコニウムの濃度 分布が不均一になったと推察された。 また，図4 (b)のSEM 写真でも, ジルコニアは試験片の表面付近の細孔に担持された ことが確認された。したがって, ジルコニウムの濃度分布はシ リカゲルの残留によって生じる試験片表面付近と中心部の細孔 径差に強く影響を受けるものと考えられる.

図 5 (a)のように, 3 回程度のジルコニア処理を行うと PGBに生じた 2 本のピークのうち，細孔径が大きい側のピーク が減少して1本のピークとなった．これは，ゾルが主として 試験片表面付近の大きい細孔中に充填されそこにジルコニアが 析出し, 多量のシリカゲルが残留する試験片内部の小さい細孔 にはゾルがほとんど入らないためと考えられる。したがって， このような方法で試験片表面付近の大きな細孔を小さくするこ とができれば，多孔質ガラスの細孔径分布を制御することがで きる. 図 6 に示したように, ジルコニア処理回数が 3 回まで は比表面積が増加した．この增加は，微粒子状のジルコニアが 細孔表面に分散して担持したためと考えられる。しかし，ジル コニア処理回数が $4 \sim 5$ 回では比表面積が減少した。これは, 細孔容積が単調に減少したことも併せて考慮すると, 処理回数 が多くなると細孔内にジルコニア微粒子が相互に接触するまで 密集して担持されたためと考えられる.これらのことは図 4 (b)のSEM 写真からも説明できる.すなわち、ジルコニア処 理回数が 3 回の場合, シリカ骨格上にジルコニア微粒子が はっきりと認められるが，5回の処理では, 微粒子同土が㠜集 し, シリカ骨格上に膜状に担持されているように観察された.

多孔質ガラスのアルカリ処理による重量減少は図 7 のよう に，ジルコニア処理によって抑制された。 また，図 8 に示し たように、ジルコニア処理回数が少ない試験片は，アルカリ処 理によって粒子状に崩壊したが，ジルコニア処理 5 回の試験 片はアルカリ処理後でも原形を留めていた．これは，細孔表面 にジルコニア微粒子が担持されることによって，多孔質ガラス 骨格がアルカリ溶液に直接接触する部分が減少するためと考え られる。しかし，原形を留めた試験片でも機械的強度は弱く， 実用に適したむのではなかった。

以上のように，ジルコニア担持法は細孔径分布の制御，特 に，試験片表面付近の大きい細孔を選択的に小さくする方法々 して, また，多孔質ガラスのアルカリ耐久性を改善する方法と して十分とはいえないが，有効であった。

\section{5. 結 論}

残留シリカゲル量が異なる多孔質ガラス試験片中にゾル-ゲ ル法でジルコニアを析出させ，ジルコニアの分布，細孔径の変 化及びアルカリ耐久性について検討し，以下のことが明らかに なった。

(1) 細孔内には 5 回のジルコニア処理で約 $12.5 \%$ の正方晶 ジルコニアが担持された.

（2）残留シリカゲルが少なく試験片全体の細孔径が大きい 場合には比較的多量のジルコニアが担持され，均一分布してい たが, 残留シリカゲルが多く試験片中心部の細孔径が小さい場 合には，ジルコニアが不均一分布していた。

（3）担持されたジルコニアは, 数〜 $10 \mathrm{~nm}$ の微粒子状で あった.

（4）ジルコニア処理で, 二元型の細孔径分布を均一な細孔 径分布に制御することができた。

（5）ジルコニアの担持で, 多孔質ガラス試験片のアルカリ 耐久性は若干改善された。 


\section{文献}

1) H. D. Hood and M. E. Nordberg, US Pat. No. 2106744 (1934).

2) M. Uo, M. Numata, M. Suzuki and E. Tamiya, J. Ceram. Soc. Japan, 100, 430-33 (1992).

3) D. Sunil, J. Sokolov, M. H. Rafailovich, B. Kotyuzhanskii, H. D. Gafney, B. J. Wilkins and A. L. Hanson, J. Appl. Phys., 74, 3768-77 (1993).

4) M. Anpo, I. Tanahashi and Y. Kubokawa, J. Phys. Chem., 84, 3440-43 (1980).

5) M. Anpo, N. Aikawa, Y. Kubokawa, M. Che, C. Louis and E. Giamello, J. Phys, Chem., 89, 5689-94 (1985).

6) T. Yazawa, H. Tanaka, K. Eguchi and T. Yamaguro, Nippon Kagaku Kaishi, 866-70 (1985).

7) R. Lodkowski, E. Kruszynska, Z. Suprynowicz and B. Buszewski, Chem. Anal., 39, 543-54 (1994).

8) S. Higashi, M. Shimizu, T. Nakashima, K. Iwata, F. Uchiyama, S. Tateno, S.Tamura and T. Setoguchi, Cancer., 75, 1245-54 (1995)

9）守屋喜郎, 西川冬旗, 近藤洋一, 山口直樹, 樋野良治, $J$. Ceram. Soc. Japan, 103, 737-39 (1995).

10）森本繁樹, セラミックス論文誌, 98, 1093-96 (1990).

11) T. Yazawa, H. Tanaka, K. Eguchi and S. Yokoyama, J. Mater. Sci., 29, 3433-40 (1994).
12) T. Yazawa, H. Tanaka, K. Eguchi and S. Yokoyama, J. Mater. Sci. Lett., 13, 494-95 (1994).

13）小山秀美，鈴木 蕃，田中実，上部隆男，東京都立工業技 術センター研究報告, 24, 61-64 (1995).

14）野上正行，蔷協，93，195-200 (1985).

15) K. Kamiya, S. Mabe, T. Yoko and K. Tanaka, Seramikkusu Ronbunshi, 97, 229-34 (1989).

16）矢沢哲夫，三宅明子，田中博史，セラミックス論文誌，99, 1094-97 (1991).

17）釣田 寧，和田啓輔, Mitsubishi Kasei $R$ \& D Review, 5, 2026 (1991).

18) A. Yasumori, K. Yamazaki, S. Shibata and M. Yamane, J. Ceram. Soc. Japan, 102, 702-07 (1994).

19) S. Imamura, S. Ishida, H. Tarumoto, Y. Saito and T. Ito, J. Chem. Soc. Faraday Trans., 89, 757-62 (1993).

20) H. Inoue, T. Matsuyama, B. Liu, T. Sakata, H. Mori and H. Yoneyama, Chem. Lett., 653-56 (1994).

21) M. Anpo, N. Akikawa, Y. Kubokawa, M. Che, C. Louis and E. Giamello, J. Phys. Soc., 89, 5017-21 (1985).

22) R. Castillo, B. Koch, P. Ruiz and B. Delmon, J. Mater. Chem., 4, 903-06 (1994).

23) K. Domen, Y. Sakata, A. Kudo, K. Maruya and T. Onishi, Bull. Chem. Soc. Jpn., 61, 359-62 (1988).

24) H. Kawamura, N. Takusagawa, S. Taruta and K. Kitajima, J. Ceram. Soc. Japan, 104, 179-84 (1996). 